\title{
ZASTOSOWANIE MODELU SWMM DO OBLICZENIA PRZEPŁYWÓW I ICH REDUKCJI PRZEZ ZBIORNIKI NA OBSZARZE LOTNISKA CHOPINA
}

\author{
Mariusz Barszcz ${ }^{\bowtie}$ \\ Wydział Budownictwa i Inżynierii Środowiska, Szkoła Główna Gospodarstwa Wiejskiego w Warszawie, Warszawa
}

\begin{abstract}
STRESZCZENIE
W pracy omówiono system retencji wód opadowych na obszarze portu lotniczego Chopina w Warszawie. Opisano adaptację modelu Storm Water Management Model (SWMM) dla badanej zlewni cząstkowej Potoku Służewieckiego. Przedstawiono wyniki kalibracji i weryfikacji modelu, które przeprowadzono na podstawie pomierzonych opadów i przepływów, jak również poziomów wody w zbiorniku retencyjnym oraz przed/ za zastawkami współpracującymi ze zbiornikami. Model SWMM zastosowano do obliczenia przepływów o prawdopodobieństwach przekroczenia 50, 20 i 10\%, a następnie do oceny redukcji tych przepływów przez zbiorniki na obszarze portu lotniczego. Stopień redukcji przepływów wynosił od 76,4 do 77,1\%.
\end{abstract}

Słowa kluczowe: port lotniczy, model SWMM, proces opad - odpływ, zbiorniki retencyjne, redukcja przepływów

\section{WSTĘP}

Do obliczania przepływów w reakcji na opady deszczu są stosowane w praktyce inżynierskiej modele o różnym stopniu złożoności, od prostych wzorów empirycznych lub zależności regresyjnych do skomplikowanych modeli matematycznych opisujących wszystkie procesy obiegu wody w zlewni (WMO, 1994; Singh, 1995; Beven, 2001). W literaturze można znaleźć jedynie nieliczne informacje na temat przydatności tych modeli do analiz w obszarach zurbanizowanych, w szczególności takich, które uwzględniają w obliczeniach transformację przepływów w sieci kanalizacyjnej lub przez zbiorniki retencyjne. W związku z tym istnieje potrzeba weryfikacji istniejących modeli przeznaczonych do obliczeń w zlewniach miejskich, w szczególności pod kątem ich stosowania w praktyce inżynierskiej.

W pracy przedstawiono wyniki analiz przeprowadzonych w zlewni miejskiej Potoku Służewieckiego za pomocą modelu Storm Water Management Model (SWMM), które dotyczą zrzutu wód opadowych z obszaru zlewni do potoku bez oceny wpływu tego zrzutu na potok. Ich zakres obejmował prognozę przepływów o prawdopodobieństwie 50, 20 i 10\% oraz ocenę wpływu istniejących zbiorników retencyjnych, zlokalizowanych na obszarze portu lotniczego Chopina w Warszawie, na redukcję tych przepływów. Wyniki obliczeń przepływów (odpływu) przedstawiono w wybranych dwóch przekrojach zlokalizowanych na Potoku Służewieckim. Omówiono system retencji wód opadowych na obszarze portu lotniczego. Przedstawiono również wyniki kalibracji i weryfikacji modelu SWMM adaptowanego dla badanej zlewni.

${ }^{\bowtie}$ mariusz_barszcz@sggw.pl 
Barszcz, M. (2017). Zastosowanie modelu SWMM do obliczenia przepływów i ich redukcji przez zbiorniki na obszarze lotniska Chopina. Acta Sci. Pol. Architectura, 16 (1), 79-91. doi: 10.22630/ASPA.2017.16.1.08.

\section{METODYKA BADAŃ}

\section{Opis zlewni i systemu retencji wód opadowych}

Zlewnia Potoku Służewieckiego jest położona w południowej części Warszawy. Jej powierzchnia do ujścia w Jeziorze Wilanowskim wynosi 55,2 $\mathrm{km}^{2}$. Przedstawione w pracy analizy dotyczą górnej część zlewni do posterunku wodowskazowego „Kłobucka” (zlokalizowanego w Potoku Służewieckim około $300 \mathrm{~m}$ poniżej portu lotniczego Chopina), który zamyka zlewnię o powierzchni $16,5 \mathrm{~km}^{2}$ (rys. 1). Wymieniony posterunek uruchomiono w ramach projektu badawczego COST/210/2006. Hydrogramy stanów wody (przeliczane na przepływy przy wykorzystaniu krzywej natężenia przepływu) były rejestrowane w tym przekroju za pomocą elektronicznego urządzenia typu Diver w przyjętych 10-minutowych przedziałach czasowych. Posterunek opadowy, zlokalizowany na obszarze portu lotniczego, należy do sieci pomiarowej IMGW.

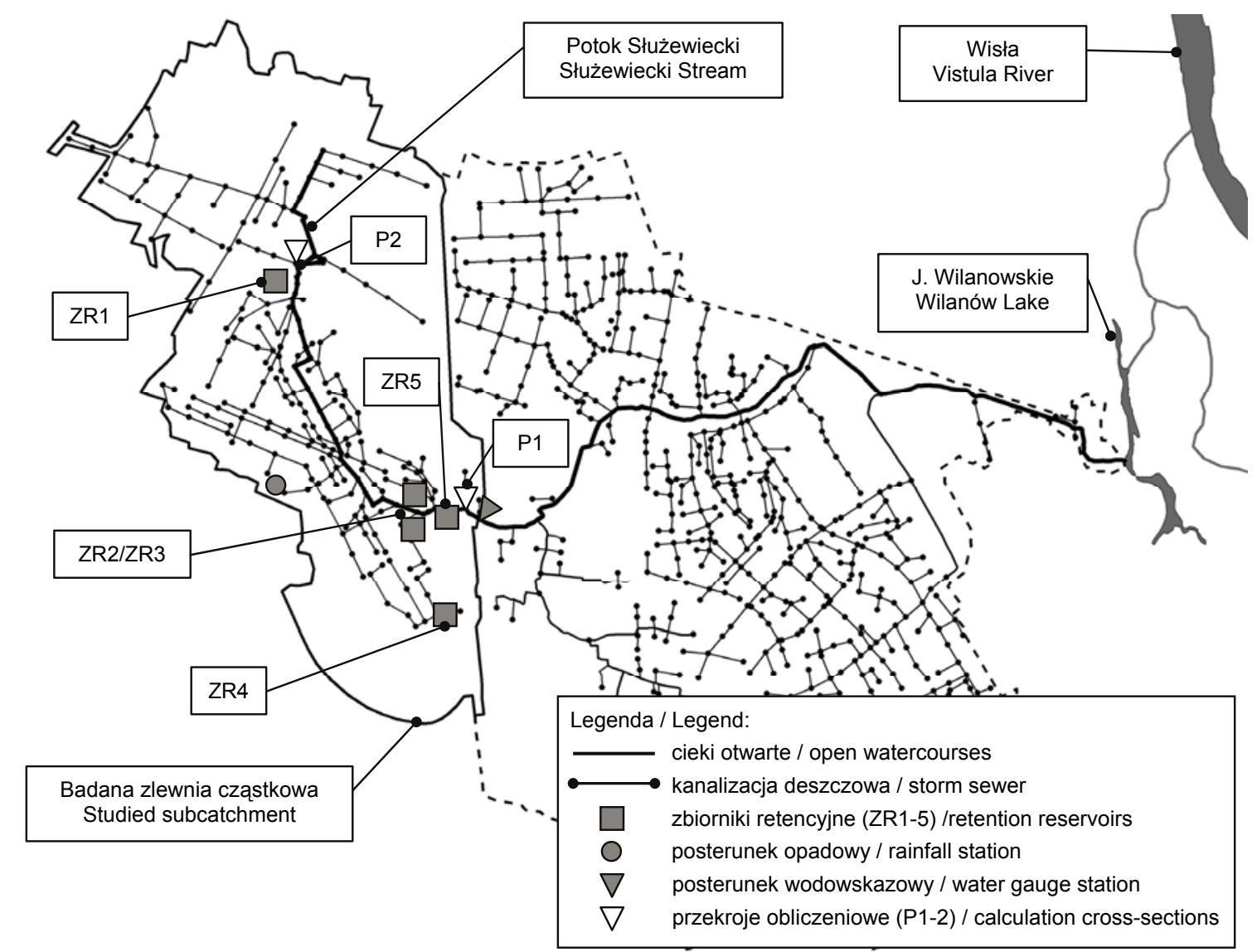

Rys. 1. System kanalizacji deszczowej i cieków w zlewni Potoku Służewieckiego

Fig. 1. The storm sewer system and watercourses in the catchment of Służewiecki Stream

Odcinek Potoku Służewieckiego od źródeł do przekroju obliczeniowego P1 jest prawie na całej długości betonowym kolektorem o przekroju kołowym (poza krótkim odcinkiem powyżej lotniska), do którego siecią kanalizacyjną odprowadzane są wody opadowe ze szczelnych powierzchni znajdujących się na obszarze badanej zlewni. Szczególnie rozbudowana sieć kanałów deszczowych występuje na obszarze portu lotniczego, a ich łączna długość wynosi około $30000 \mathrm{~m}$. Średnica kolektora, którym płynie Potok Służewiecki na obszarze portu lotniczego, wynosi 
Barszcz, M. (2017). Zastosowanie modelu SWMM do obliczenia przepływów i ich redukcji przez zbiorniki na obszarze lotniska Chopina. Acta Sci. Pol. Architectura, 16 (1), 79-91. doi: 10.22630/ASPA.2017.16.1.08.

na przeważającej długości 2,5 m, a w górnej jego części - 1,8 m. W ostatnich latach przeprowadzono renowację kanałów deszczowych na terenie lotniska (wymianę rur kanalizacyjnych), która pozwoliła uzyskać ich dobry stan techniczny i usprawnienie odpływu wód opadowych. Renowacja dotyczyła kanałów o łącznej długości $8815 \mathrm{~m}$.

$\mathrm{Na}$ obszarze portu lotniczego Chopina znajduje się 5 podziemnych zbiorników wyrównawczych (rys. 1), których pojemność retencyjna wynosi łącznie $42490 \mathrm{~m}^{3}$. Ich budowę ukończono w czerwcu 2005 roku. Zbiornik oznaczony skrótem ZR1 (zbiornik boczny), o pojemności około $8000 \mathrm{~m}^{3}$, położony jest na początku portu lotniczego. Przechwytuje on wody opadowe, które dopływają do lotniska kanałem z górnej części zlewni, użytkowanej głównie jako tereny mieszkalne i przemysłowe.

Zbiorniki ZR2 i ZR3, których pojemność retencyjna wynosi odpowiednio 11130 i $15620 \mathrm{~m}^{3}$, znajdują się w dolnej części lotniska po obu stronach kolektora (Potoku Służewieckiego). Na rysunku 2A pokazano zdjęcie przedstawiające fragment zbiornika ZR3 (jedną z komór, na które jest podzielony zbiornik) oraz w tle zastawkę umieszczoną w kanale. Zadaniem tych zbiorników jest przede wszystkim retencja odpływu powstającego na obszarze lotniska. Gromadzenie wód opadowych w tych zbiornikach rozpoczyna się w momencie opuszczenia zastawki w kanale głównym. Widok tej zastawki i jej mechanizmu wyciągowego (znajdującego się nad powierzchnią terenu) pokazano na rysunku 3. Zbiornik ZR4, o pojemności $1900 \mathrm{~m}^{3}$, zlokalizowany jest przy budynku towarowej obsługi lotniskowej.
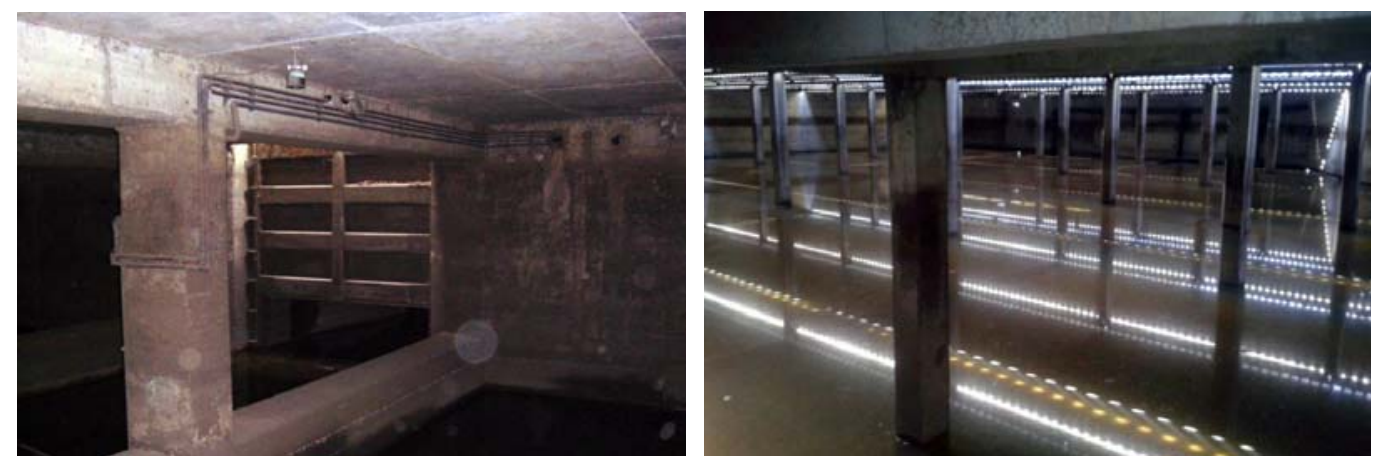

Rys. 2. Zbiorniki zamknięte ZR3 (A) oraz ZR5 (B)

Fig. 2. Closed reservoirs of ZR3 (A) and of ZR5 (B)
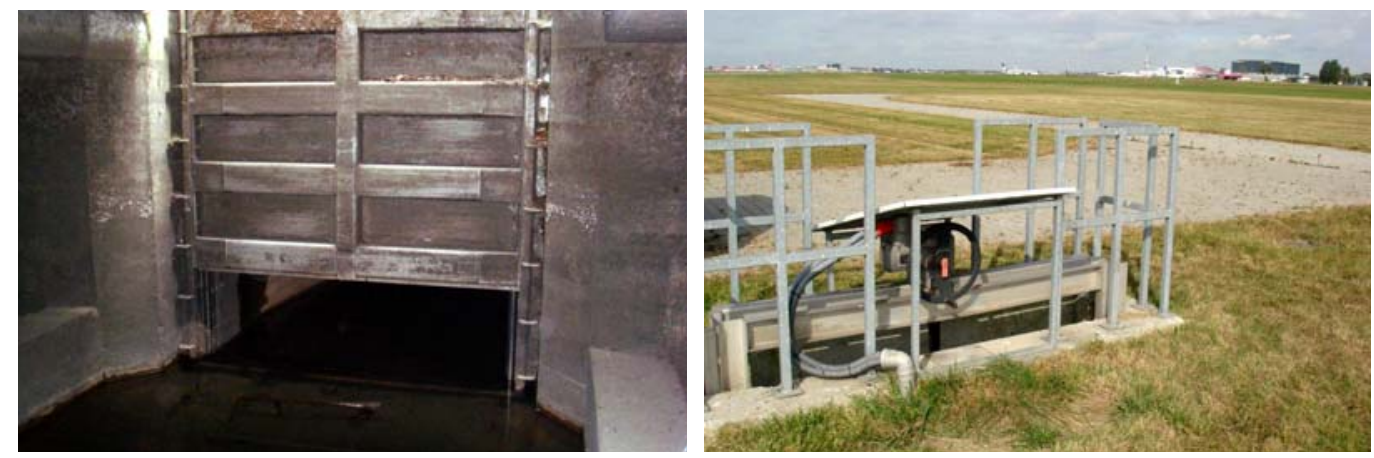

Rys. 3. Zastawka zlokalizowana w kanale głównym przy zbiornikach ZR2-3: A - widok z poziomu zbiorników; $\mathrm{B}$ - widok z poziomu terenu

Fig. 3. Control gate located in the main channel at the reservoirs of ZR2-3: A - view from the interior of reservoirs; $\mathrm{B}$ - view from the ground 
Barszcz, M. (2017). Zastosowanie modelu SWMM do obliczenia przepływów i ich redukcji przez zbiorniki na obszarze lotniska Chopina. Acta Sci. Pol. Architectura, 16 (1), 79-91. doi: 10.22630/ASPA.2017.16.1.08.

Zbiornik ZR5 jest najniżej położony w systemie odwodnienia lotniska i włączony do układu technologicznego oczyszczalni wód deszczowych, której zadaniem jest przede wszystkim usunięcie ze ścieków osadów - głównie mineralnych, oraz węglowodorów ropopochodnych. Pojemność retencyjna tego zbiornika oraz osadnika zlokalizowanego przy tym zbiorniku i służącego do oczyszczania wód opadowych z zawiesin wynosi łącznie $5840 \mathrm{~m}^{3}$. Z dokumentacji projektowej systemu odwadniania lotniska wynika, że maksymalny dopływ do zbiornika ZR5 wynosi $5,31 \mathrm{~m}^{3} \cdot \mathrm{s}^{-1}$. Jeżeli po wystapieniu deszczy nawalnych dopływ do zbiornika jest większy niż $5,31 \mathrm{~m}^{3} \cdot \mathrm{s}^{-1}$, to następuje otwarcie zespołu zastawek głównych, co skutkuje przepuszczaniem ścieków deszczowych na wprost przez kolektor (Potok Służewiecki). Tuż poniżej wylotu kolektora do kanału otwartego Potoku Służewieckiego przyjęto w tych analizach przekrój obliczeniowy P1 (poniżej zbiornika ZR5).

Opisane zbiorniki retencyjne posiadają komory regulacyjne, w których odbywa się sterowanie wysokością podnoszenia i opuszczania zastawek (zazwyczaj sterowanie odbywa się w sposób automatyczny, ale istnieje możliwość ręcznej regulacji), którego celem jest zapewnienie przepływu poniżej każdej komory/zbiornika mniejszego niż $1,53 \mathrm{~m}^{3} \cdot \mathrm{s}^{-1}$. Zgodnie z pozwoleniem wodnoprawnym wydanym dnia 14 czerwca 2007 roku (Decyzja..., 2007) jest to wartość dopuszczalnego przepływu na wylocie z oczyszczalni wód deszczowych (w kanale poniżej lotniska), dalej w pracy określany jako „przepływ dopuszczalny”. Istniejący system retencji wód opadowych (zbiorników i zastawek współpracujących z tymi zbiornikami) powinien, zgodnie z projektem, sprawnie działać przy wystapieniu opadu miarodajnego o natężeniu $1321 \cdot \mathrm{s}^{-1} \cdot \mathrm{ha}^{-1} \mathrm{i}$ czasie trwania $15 \mathrm{mi}-$ nut. Wartość tego natężenia opadu odpowiada zdarzeniu o prawdopodobieństwie $20 \%$, przy założeniu, że jest ono obliczane za pomocą wzoru Błaszczyka (Błaszczyk, Stamatello i Błaszczyk, 1983).

\section{Model zlewni badawczej}

Do analizy procesu opad - odpływ w badanej zlewni i oceny redukcji przepływów przez zbiorniki wykorzystano model SWMM (Storm Water Management Model) w wersji 5.1, opracowany przez Agencję Ochrony Środowiska Stanów Zjednoczonych (U.S. Environmental Protection Agency - EPA).

Pod względem struktury i przedmiotu modelowania model SWMM można zakwalifikować jako model komponentów zlewni, opisujący procesy zachodzące w poszczególnych środowiskach występowania wody w zlewni lub jako model częściowo integralny (Ozga-Zielińska i Brzeziński, 1997). Biorąc pod uwagę inne kryteria klasyfikacji, SWMM należy do modeli genetycznych, dynamicznych, nieliniowych, jak również do modeli o parametrach rozłożonych. Szeroki opis modelu i przykłady jego zastosowania w praktyce inżynierskiej można znaleźć w pracach: Warwicka i Tadepalli (1991), Barco, Wonga i Stenstroma (2008), Barszcza $(2009,2015 a, 2015 b)$.

Opracowanie modelu SWMM dla badanej zlewni cząstkowej Potoku Służewieckiego do profilu wodowskazowego „Kłobucka” polegało na utworzeniu w oknie programu komputerowego obiektów, które reprezentują obiekty rzeczywistego systemu, a następnie na określeniu zależności pomiędzy nimi oraz wartości ich parametrów. Obszar zlewni został podzielony w modelu na zbiór zlewni (obszarów) cząstkowych, które wydzielono dla uwzględnienia przestrzennej zmienności modelowanych procesów hydrologicznych (rys. 4). Głównym kryterium podziału zlewni był charakter użytkowania i związany z tym różny udział powierzchni nieprzepuszczalnych. Oprócz systemu hydrologicznego utworzono w modelu również obiekty systemu hydraulicznego, m.in. kanały otwarte, przewody i studzienki kanalizacyjne, zbiorniki retencyjne (rys. 4).

Wartości parametrów obiektów przyjęto na podstawie danych ustalonych dla fizycznie mierzalnych charakterystyk lub wartości zalecanych w podręczniku modelu (Rossman, 2010), jak również w innej literaturze (Peterson i Wicks, 2006; Park, Lee, Park i Ha, 2008). Charakterystyki i wymiary obiektów zlokalizowanych na obszarze portu lotniczego, takich jak przewodów sieci kanalizacyjnej i zbiorników, przyjęto zgodnie $\mathrm{z}$ danymi technicznymi uzyskanymi $\mathrm{z}$ dokumentacji projektowej i powykonawczej systemu odwodnienia lotniska. 

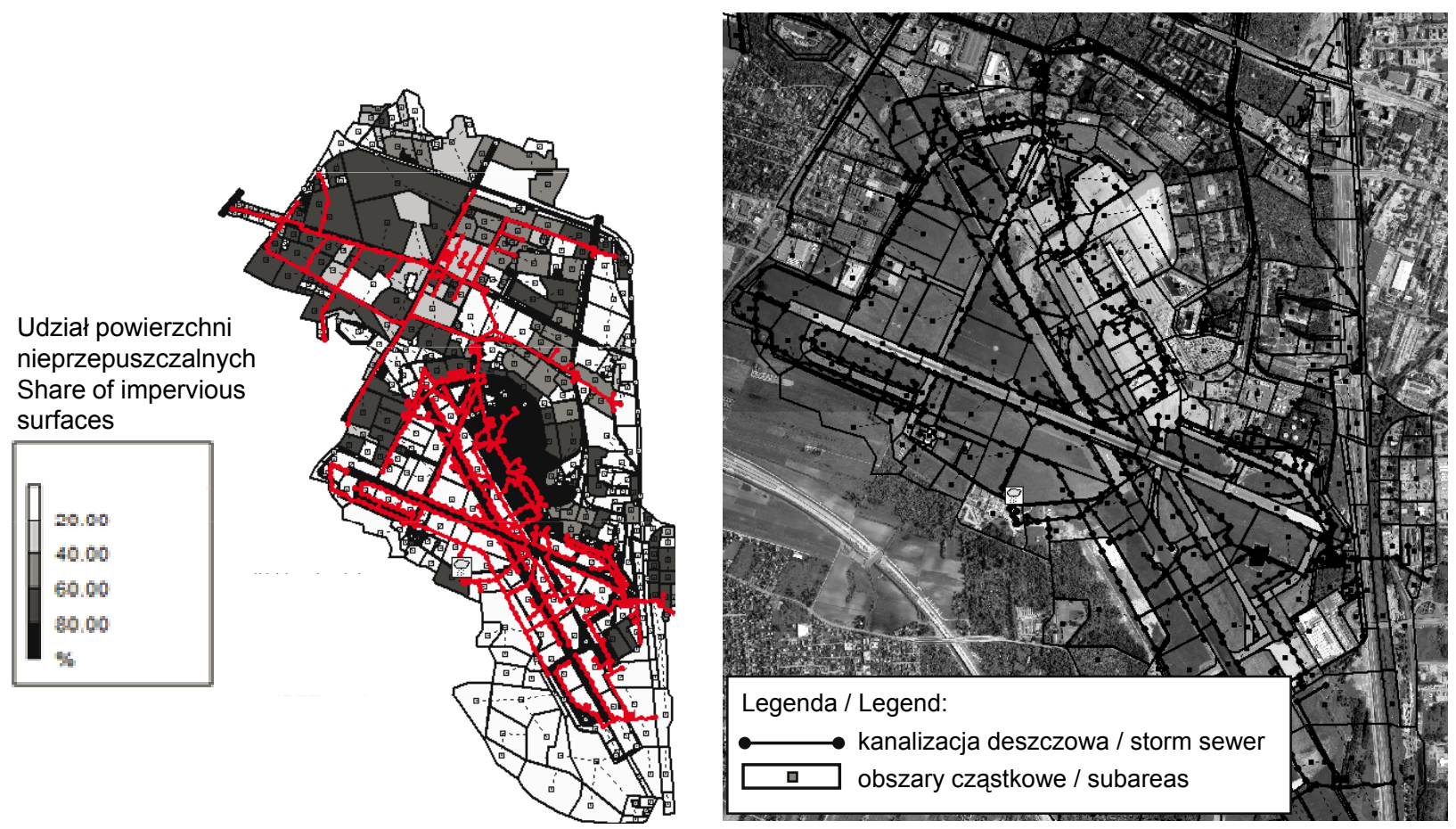

Rys. 4. Badana zlewnia cząstkowa (A) oraz obszar portu lotniczego (B) w modelu SWMM

Fig. 4. The study subcatchment (A) and the area of airport (B) in the SWMM model

W modelu zlewni uwzględniono następujące obiekty:

1. Posterunek opadowy, zlokalizowany w miejscu istniejącej stacji meteorologicznej na obszarze portu lotniczego.

2. Zlewnie (obszary) cząstkowe - utworzono 702 zlewnie. Dla każdej z nich określono wartości 13 parametrów, m.in. wielkość powierzchni, spadek terenu, udział powierzchni nieprzepuszczalnych, wysokość retencji terenowej dla powierzchni przepuszczalnych i nieprzepuszczalnych, współczynniki szorstkości terenu, wartości parametru CN.

3. Kanały otwarte i przewody kanalizacji deszczowej, punkty węzłowe (usytuowane w miejscu lokalizacji studzienek kanalizacyjnych lub w miejscu określającym zmianę charakterystyki kanałów) - utworzono 763 kanały. Dla każdego kanału określono m.in. kształt, średnicę, długość, jak również wartości parametrów hydraulicznych. W punktach węzłowych podano m.in. rzędne dna studzienek oraz zagłębienie pod powierzchnią terenu.

4. Zbiorniki retencyjne ze sterowanym odpływem (kryte) - utworzono 5 zbiorników (ZR1-5) oraz osadnik wód deszczowych na terenie oczyszczalni ścieków (współpracujący ze zbiornikiem ZR5). Dla każdego z nich określono m.in. wymiary (powierzchnię i wysokość) oraz rzędną dna.

5. Zastawki w kanałach, służące do sterowania przepływami poniżej poszczególnych zbiorników (również pompy do opróżniania zbiorników). Dla każdej z nich ustalono m.in. wymiary oraz krzywe sterowania (wysokość otwarcia zastawki w relacji do przepływów).

W analizach przeprowadzonych za pomocą modelu SWMM do ustalenia opadu efektywnego dla obszarów przepuszczalnych wybrano metodę CN-SCS (USDA-SCS, 1975; SCS, 1986). Opad efektywny (odpływ) dla obszarów nieprzepuszczalnych był obliczany jako różnica pomiędzy wysokością opadu całkowitego a wysokością strat początkowych, którą definiuje się w modelu poprzez wysokość retencji terenowej dla obszarów 
nieprzepuszczalnych. Ustalony odpływ z pojedynczych obszarów cząstkowych był przekazywany w modelu do sąsiednich obszarów i/lub do systemu hydraulicznego zlewni. Do obliczania transformacji fali wezbraniowej w kanałach zastosowano tzw. model fali dynamicznej (Szymkiewicz, 2000), w którym zmiana kształtu fali jest opisana przez układ równań przepływu nieustalonego de Saint-Venanta.

\section{WYNIKI BADAŃ I DYSKUSJA}

\section{Kalibracja i weryfikacja modelu zlewni}

Do identyfikacji modelu (w którym występują zarówno parametry określane w wyniku ich pomiaru, jak i w wyniku optymalizacji) oraz sprawdzenia poprawności modelu (weryfikacji przeprowadzonej na danych niezależnych) wykorzystano wysokość opadów pomierzonych na stacji meteorologicznej należącej do IMGW (zlokalizowanej na obszarze portu lotniczego), które stanowiły wejście do modelu. Przyjęto założenie, że wysokość opadu na obszarze całej zlewni jest równa wysokości zmierzonej dla poszczególnych epizodów na stacji meteorologicznej.

Do kalibracji modelu wykorzystano dane pomiarowe dla dwóch zdarzeń, pomierzone przez Biuro Inżynierii i Utrzymania Lotniska Chopina. Oprócz wysokości opadów wykorzystano następujące dane: hydrogramy przepływów w kanale głównym poniżej zbiornika ZR5 (w tym miejscu przyjęto lokalizację przekroju obliczeniowego P1), poziomy wody w kanałach deszczowych przed/za zastawkami współpracującymi ze zbiornikami retencyjnymi ZR1, ZR2-3 oraz poziomy wody w zbiorniku ZR1. Identyfikacja modelu polegała na uzyskaniu możliwie największej zgodności pomiędzy wartościami tych charakterystyk uzyskanych z pomiarów i odpowiadającymi im wartościami uzyskanymi z modelu, przede wszystkim w odniesieniu do przepływów maksymalnych hydrogramów pomierzonych i symulowanych w przekroju P1. Analizowano również zgodność wykresów obu przebiegów (zbieżność) przepływów w czasie 24 godzin trwania zdarzenia na podstawie wizualnej oceny. $\mathrm{Na}$ rysunku 5 przedstawiono hydrogramy przepływów dla jednego z analizowanych zdarzeń, uzyskane z modelu i pomiarów w przekroju P1. Dla porównania zamieszczono również hydrogram przepływów pomierzony w przekroju wodowskazowym, położonym poniżej przekroju P1. Ocenę zgodności przepływów maksymalnych dla analizowanych zdarzeń dokonano za pomocą błędu względnego, który obliczono z równania:

$$
\delta=\frac{Q_{\mathrm{obl}}-Q_{\mathrm{obs}}}{Q_{\mathrm{obs}}} \cdot 100 \%
$$

gdzie: $\delta$ - błąd względny,

$Q_{\text {obs }}$ - obserwowany przepływ maksymalny hydrogramu $\left[\mathrm{m}^{3} \cdot \mathrm{s}^{-1}\right]$,

$Q_{\mathrm{obl}}-$ obliczony przepływ maksymalny, uzyskany z modelu SWMM $\left[\mathrm{m}^{3} \cdot \mathrm{s}^{-1}\right]$.

Wartości błędu względnego wynosiły 7,8 i-6,3\% (tab. 1).

Tabela 1. Wyniki kalibracji modelu w przekroju P1

Table 1. The results of model calibration in the cross-section of P1

\begin{tabular}{cccccc}
\hline & Wysokość opadu & Cza trwania opadu & \multicolumn{2}{c}{ Przepływ - Flow } & Błąd względny \\
\cline { 5 - 6 } Date of the event & Rainfall depth & Time of rainfall & $\begin{array}{c}\text { obserwowany } \\
\text { measured }\end{array}$ & $\begin{array}{c}\text { obliczony } \\
\text { calculated }\end{array}$ & $\begin{array}{c}\text { Relative error } \\
{[\%]}\end{array}$ \\
\hline 06.08 .2006 & {$[\mathrm{~mm}]$} & {$[\mathrm{min}]$} & 6,398 & 6,897 & 7,8 \\
15.08 .2008 & 24,2 & 180 & 1,548 & 1,450 & $-6,3$ \\
\hline
\end{tabular}


Barszcz, M. (2017). Zastosowanie modelu SWMM do obliczenia przepływów i ich redukcji przez zbiorniki na obszarze lotniska Chopina. Acta Sci. Pol. Architectura, 16 (1), 79-91. doi: 10.22630/ASPA.2017.16.1.08.

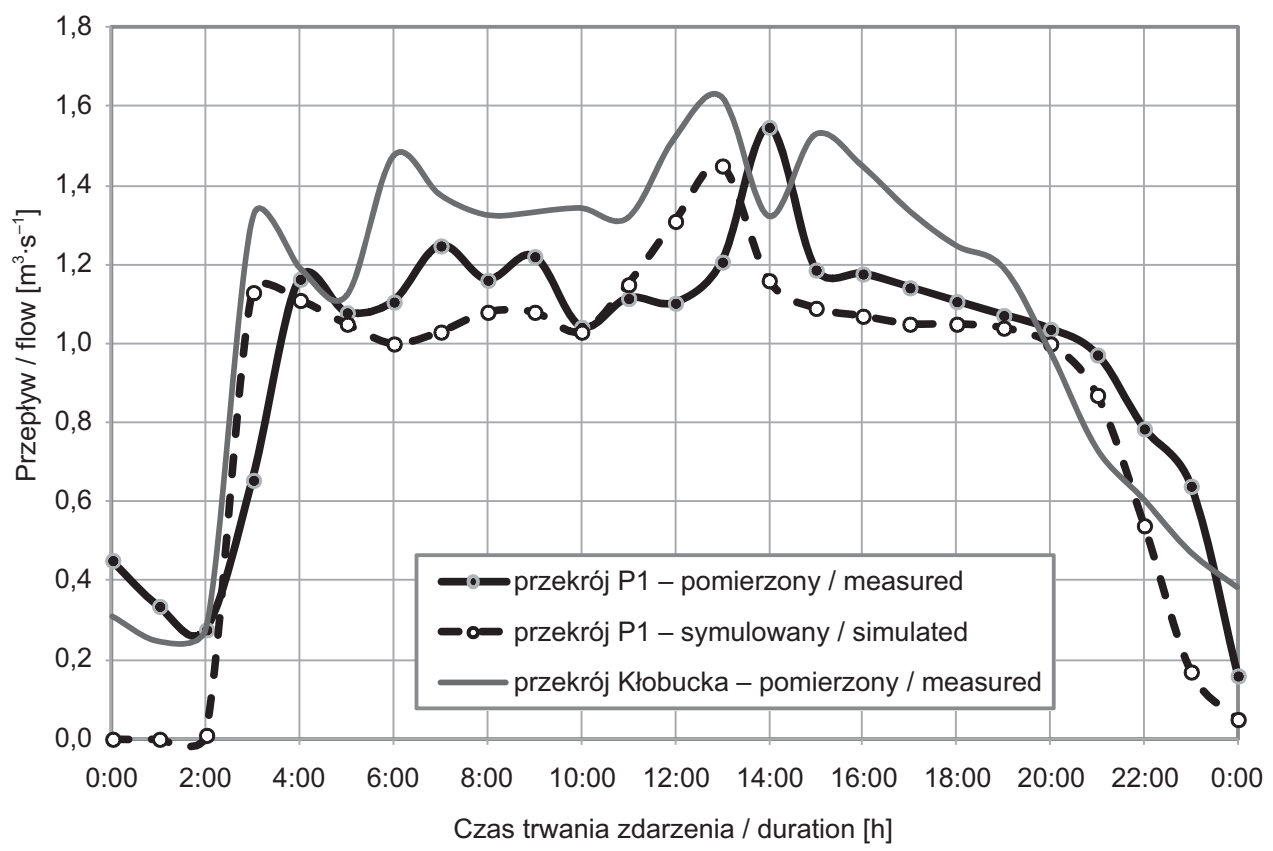

Rys. 5. Hydrogramy przepływów pomierzone i symulowane w reakcji na opad w dniu 15.08.2008 r.

Fig. 5. Hydrographs of flows measured and simulated in response to rainfall on 15.08.2008

Aby uzyskać zgodność pomiędzy hydrogramami przepływów i innymi wymienionymi charakterystykami uzyskanymi z pomiarów i z modelu, działania optymalizacyjne w modelu sprowadzono przede wszystkim do ustalenia przebiegu położenia zastawek w czasie 24 godzin trwania zdarzeń wykorzystanych do kalibracji. Nie dysponowano rzeczywistymi danymi o położeniu zastawek, zatem w modelu przyjmowano różne wysokości otwarcia zastawki (wyrażone w postaci ułamka jedności) w odniesieniu do różnych wartości przepływów (w całym zakresie ich zmienności) w kanale powyżej określonej zastawki, aż do uzyskania największej zgodności pomiędzy przepływami i pozostałymi charakterystykami pomierzonymi i symulowanymi. W ten sposób ustalono „krzywą sterowania" dla każdej zastawki uwzględnionej w modelu, tj. zależność pomiędzy przepływami w kanale i wysokością otwarcia zastawki. Wymienione parametry podano w modelu w zakładce „Control Curve Editor”. Natomiast w zakładce „Controls” podano warunki aktywacji poszczególnych zastawek (również pomp), które uzależniono od wartości przepływów w kanałach deszczowych, poziomów wody w kanałach oraz w zbiornikach.

W praktyce sterowanie wysokością otwarcia poszczególnych zastawek współpracujących ze zbiornikami na obszarze portu lotniczego odbywa się w sposób automatyczny (istnieje również możliwość sterowania ręcznego), w zależności od wartości przepływów i/lub poziomów wody w kanałach/zbiornikach. Jest ono tak zaprogramowane, aby przepływ w kolektorze (Potoku Służewieckim) poniżej określonej zastawki był mniejszy niż $1,53 \mathrm{~m}^{3} \cdot \mathrm{s}^{-1} \mathrm{i}$ jednocześnie poziom wody $\mathrm{w}$ kanałach lub zbiornikach był mniejszy od dopuszczalnego.

Weryfikację modelu przeprowadzono na podstawie 11 zdarzeń opad - odpływ. Hydrogramy przepływów zostały pomierzone przez Katedrę Inżynierii Wodnej SGGW w latach 2007-2008 (w ramach projektu COST/210/2006) w przekroju wodowskazowym „Kłobucka”, zlokalizowanym w Potoku Służewieckim około $400 \mathrm{~m}$ poniżej przekroju obliczeniowego $\mathrm{P} 1$. Wartości błędu względnego, ustalone na podstawie pomierzonych i symulowanych przepływów za pomocą równania (1), wynosiły dla analizowanych zdarzeń od 2,2 do 22,4\% (tab. 2). Wartość maksymalnego błędu względnego była mniejsza niż $25 \%$, którą przyjęto jako umowną granicę akceptacji modelu, zgodnie z wyjaśnieniem podanym w pracy Ozgi-Zielińskiej i Brzezińskiego (1997). Wartości 
Barszcz, M. (2017). Zastosowanie modelu SWMM do obliczenia przepływów i ich redukcji przez zbiorniki na obszarze lotniska Chopina. Acta Sci. Pol. Architectura, 16 (1), 79-91. doi: 10.22630/ASPA.2017.16.1.08.

średniego błędu oraz mediany, obliczone dla wartości bezwzględnych błędów symulacji (zaniedbano znaki minus), wynosiły odpowiednio 12,7 i $14,1 \%$.

Do weryfikacji modelu zastosowano również inne statystyczne miary jakości modelu, które omówiono w pracy Ozgi-Zielińskiej i Brzezińskiego (1997). Są to: względny średniokwadratowy błąd resztowy (WBR), stosunek wartości średnich (SWS), współczynnik korelacji liniowej (R) oraz specjalny współczynnik korelacji (RS). Wartości tych miar, ustalone na podstawie obserwowanych i obliczonych przepływów maksymalnych dla zdarzeń zestawionych w tabeli 2 , wynosiły: $\mathrm{WBR}=14,6, \mathrm{SWS}=1,04, \mathrm{R}=0,91, \mathrm{RS}=0,99$. Wartości te wskazują, że model jest co najmniej dobry i może być przyjęty.

Tabela 2. Wyniki weryfikacji modelu w przekroju wodowskazowym „Kłobucka”

Table 2. The results of model verification in the water gauge station of "Kłobucka"

\begin{tabular}{|c|c|c|c|c|c|}
\hline \multirow{3}{*}{$\begin{array}{c}\text { Data zdarzenia } \\
\text { Date of the event }\end{array}$} & \multirow{3}{*}{$\begin{array}{l}\text { Wysokość opadu } \\
\text { Rainfall depth } \\
{[\mathrm{mm}]}\end{array}$} & \multirow{2}{*}{$\begin{array}{l}\text { Cza trwania opadu } \\
\text { Time of rainfall }\end{array}$} & \multicolumn{2}{|c|}{$\begin{array}{l}\text { Maksymalny przepływ } \\
\text { Maximum flow }\end{array}$} & \multirow{2}{*}{$\begin{array}{l}\text { Błąd względny } \\
\text { Relative error }\end{array}$} \\
\hline & & & $\begin{array}{l}\text { obserwowany } \\
\text { measured }\end{array}$ & $\begin{array}{l}\text { obliczony } \\
\text { calculated }\end{array}$ & \\
\hline & & {$[\mathrm{min}]$} & \multicolumn{2}{|c|}{$\left[\mathrm{m}^{3} \cdot \mathrm{s}^{-1}\right]$} & {$[\%]$} \\
\hline 13.06.2007 & 16,4 & 50 & 1,298 & 1,481 & 14,1 \\
\hline 21.06 .2007 & 9,8 & 230 & 1,079 & 0,914 & $-15,3$ \\
\hline 02.07 .2007 & 8,6 & 90 & 0,804 & 0,856 & 6,5 \\
\hline 22.07 .2007 & 9,4 & 30 & 1,005 & 0,894 & $-11,0$ \\
\hline 27.07.2007 & 11,2 & 50 & 0,940 & 1,151 & 22,4 \\
\hline 05.09 .2007 & 14,6 & 620 & 1,079 & 1,245 & 15,4 \\
\hline 28.09 .2007 & 2,6 & 40 & 0,504 & 0,515 & 2,2 \\
\hline 11.07.2008 & 3,2 & 20 & 0,604 & 0,576 & $-4,6$ \\
\hline 02.08 .2008 & 8,8 & 60 & 0,729 & 0,864 & 18,5 \\
\hline 09.08 .2008 & 6,8 & 60 & 0,659 & 0,796 & 20,8 \\
\hline 15.08 .2008 & 24,2 & 180 & 1,622 & 1,479 & $-8,8$ \\
\hline Minimum / minimum & 2,6 & 20 & 0,504 & 0,515 & 2,2 \\
\hline Maksimum / maximum & 24,2 & 620 & 1,622 & 1,481 & 22,4 \\
\hline Średnia / average & 10,5 & 130 & 0,938 & 0,979 & 12,7 \\
\hline Mediana / median & 9,4 & 60 & 0,940 & 0,894 & 14,1 \\
\hline
\end{tabular}

\section{Obliczenie przepływów i ich redukcji przez zbiorniki}

Model SWMM, adaptowany dla badanej zlewni, zastosowano do obliczenia przepływów o prawdopodobieństwie przekroczenia 50, 20 i 10\% w reakcji na opady o tym samym prawdopodobieństwie i czasie krytycznym trwania opadu. Ponadto analizy przeprowadzono dla opadu o natężeniu jednostkowym $132 \mathrm{l} \cdot \mathrm{s}^{-1} \cdot \mathrm{ha}^{-1} \mathrm{i}$ czasie trwania 15 minut, który był opadem miarodajnym w obliczeniach projektowych zbiorników retencyjnych na obszarze lotniska. Prawdopodobieństwo tego opadu wynosi $20 \%$ przy założeniu, że natężenie jednostkowe jest obliczane według formuły Błaszczyka (Błaszczyk i in. 1983). Obliczono również przepływ w reakcji na opad 
Barszcz, M. (2017). Zastosowanie modelu SWMM do obliczenia przepływów i ich redukcji przez zbiorniki na obszarze lotniska Chopina. Acta Sci. Pol. Architectura, 16 (1), 79-91. doi: 10.22630/ASPA.2017.16.1.08.

deszczu o prawdopodobieństwie $20 \%$ i czasie trwania 15 minut, którego wysokość ustalono według formuły Bogdanowicz i Stachý'ego (1997).

W celu ustalenia czasu krytycznego opadu przyjmowano w modelu wysokości opadów o określonym prawdopodobieństwie przekroczenia dla różnego czasu trwania (w zakresie od 15 do 220 minut), aż do uzyskania w reakcji na te opady największych wartości przepływów maksymalnych w przekrojach obliczeniowych. Do obliczenia wysokości opadów zastosowano formułę zaproponowaną przez Bogdanowicz i Stachý’ego. Przyjęto stały rozkład opadu w czasie trwania opadu i jednakową wysokość opadu na obszarze całej zlewni.

W tabeli 3 podano wartości przepływów o prawdopodobieństwie 50, 20 i 10\%, uzyskane z modelu w przekrojach obliczeniowych P1 i P2, które znajdują się w Potoku Służewieckim odpowiednio na końcu i na początku portu lotniczego - w kanale otwartym poniżej zbiornika ZR5 oraz w kolektorze powyżej zbiornika ZR1 (rys. 1). Przepływy obliczone w przekroju P2 zawierały się w zakresie od 3,676 do $5,436 \mathrm{~m}^{3} \cdot \mathrm{s}^{-1}$, a w przekroju P1 - od 1,179 do $1,974 \mathrm{~m}^{3} \cdot \mathrm{s}^{-1}$. W wyniku retencji wód opadowych w zbiornikach (redukcji przepływów większych od przepływu dopuszczalnego, wynoszącego $1,53 \mathrm{~m}^{3} \cdot \mathrm{s}^{-1}$ ) przepływy w przekroju P1 były znacznie mniejsze niż w przekroju P2. Stopień redukcji tych przepływów obliczono z równania:

$$
R=\frac{Q_{P 2}-Q_{P 1}}{Q_{P 2}} \cdot 100 \%
$$

gdzie: $R$ - stopień redukcji,

$Q_{P 1}$ - przepływ maksymalny hydrogramu w przekroju $\mathrm{P}_{1}\left[\mathrm{~m}^{3} \cdot \mathrm{s}^{-1}\right]$,

$Q_{P 2}-$ przepływ maksymalny hydrogramu w przekroju $\mathrm{P}_{2}\left[\mathrm{~m}^{3} \cdot \mathrm{s}^{-1}\right]$.

Wartość stopnia redukcji wynosiła od 63,2 do 67,9\%.

Tabela 3. Wartości charakterystyk opadów i przepływów obliczonych dla scenariusza ze zbiornikami

Table 3. Values of characteristics of rainfalls and flows calculated for scenarios with reservoirs

\begin{tabular}{|c|c|c|c|c|c|c|c|}
\hline \multirow{3}{*}{$\begin{array}{c}\text { Prawdopodo- } \\
\text { bieństwo } \\
\text { Probability } \\
{[\%]}\end{array}$} & \multirow{2}{*}{$\begin{array}{l}\text { Czas trwania } \\
\text { opadu } \\
\text { Time of rainfall }\end{array}$} & \multirow{2}{*}{$\begin{array}{c}\text { Czas krytyczny } \\
\text { opadu } \\
\text { Critical time }\end{array}$} & \multirow{3}{*}{$\begin{array}{l}\text { Natężenie } \\
\text { opadu } \\
\text { Intensity } \\
\text { of rainfall } \\
{\left[1 \cdot \mathrm{s}^{-1} \cdot \mathrm{ha}^{-1}\right]}\end{array}$} & \multirow{3}{*}{$\begin{array}{c}\text { Wysokość } \\
\text { opadu } \\
\text { Rainfall depth } \\
\\
{[\mathrm{mm}]}\end{array}$} & \multicolumn{2}{|c|}{$\begin{array}{l}\text { Przepływ w przekroju } \\
\text { Flow in cross-section }\end{array}$} & \multirow{4}{*}{$\begin{array}{c}\text { Redukcja } \\
\text { przepływu } \\
\text { Flow } \\
\text { reduction } \\
{[\%]} \\
65.5\end{array}$} \\
\hline & & & & & P1 & P2 & \\
\hline & \multicolumn{2}{|c|}{$[\mathrm{min}]$} & & & \multicolumn{2}{|c|}{$\left[\mathrm{m}^{3} \cdot \mathrm{s}^{-1}\right]$} & \\
\hline 50 & - & 170 & - & 25,6 & 1,502 & 4,359 & \\
\hline \multirow{3}{*}{20} & 15 & - & 132,0 & 11,9 & 1,179 & 3,676 & 67,9 \\
\hline & 15 & - & - & 19,0 & 1,493 & 4,053 & 63,2 \\
\hline & - & 190 & - & 37,5 & 1,798 & 5,116 & 64,9 \\
\hline 10 & - & 180 & - & 44,0 & 1,974 & 5,436 & 63,7 \\
\hline
\end{tabular}

Przepływ obliczony w przekroju P1 w reakcji na opad, który był opadem miarodajnym w obliczeniach projektowych istniejących zbiorników na obszarze lotniska, wynosił $1,179 \mathrm{~m}^{3} \cdot \mathrm{s}^{-1}$, a zatem był mniejszy od przepływu dopuszczalnego (tab. 3). Przepływ wynoszący $1,493 \mathrm{~m}^{3} \cdot \mathrm{s}^{-1}$, obliczony dla opadu o prawdopodobieństwie 20\% i czasie trwania 15 minut, którego wysokość ustalono według formuły Bogdanowicz i Stachý’ego, również był mniejszy od przepływu dopuszczalnego. Analiza wykazała, że czas trwania opadu 15 minut nie był czasem krytycznym. Przepływ wywołany opadem o prawdopodobieństwie 20\% i czasie krytycznym 190 minut wynosił 
$1,798 \mathrm{~m}^{3} \cdot \mathrm{s}^{-1}$, a więc był większy od przepływu dopuszczalnego. Przepływ w przekroju P1 o prawdopodobieństwie $10 \%$ był również większy od przepływu dopuszczalnego, natomiast przepływ o prawdopodobieństwie $50 \%$ był nieznacznie od niego mniejszy.

W tabeli 4 podano wartości przepływów o prawdopodobieństwie 50, 20 i 10\%, obliczone w przekrojach P1 i P2 dla scenariusza, który zakładał niewystępowanie zbiorników na obszarze portu lotniczego (taki stan zlewni odpowiada rzeczywistości przed $2005 \mathrm{r}$.). Przepływy w przekroju P2 wynosiły od 4,312 do $5,624 \mathrm{~m}^{3} \cdot \mathrm{s}^{-1}$, a w przekroju P1 (poniżej portu lotniczego) - od 6,361 do $8,560 \mathrm{~m}^{3} \cdot \mathrm{s}^{-1}$. Różnica przepływów prognozowanych $\mathrm{w}$ tych przekrojach wynosiła od 2,049 do $2,936 \mathrm{~m}^{3} \cdot \mathrm{s}^{-1}$. Ta różnica przepływów jest wynikiem zasilania Potoku Służewieckiego wodami opadowymi, odpływającymi z obszaru portu lotniczego poprzez kanalizację deszczową. Natomiast przepływy w przekroju P2 są wynikiem zasilania Potoku Służewieckiego wodami opadowymi z górnej części zlewni, znajdującej się powyżej portu lotniczego (użytkowanej głównie jako tereny mieszkalne i przemysłowe). Wartości przepływów, obliczone w przekroju P1 dla scenariusza zakładającego brak zbiorników, były dużo większe od przepływu dopuszczalnego $\left(1,53 \mathrm{~m}^{3} \cdot \mathrm{s}^{-1}\right)$.

Tabela 4. Wartości przepływów obliczonych dla scenariuszy bez zbiorników i ze zbiornikami

Table 4. Values of flows calculated for scenarios without reservoirs and with reservoirs

\begin{tabular}{|c|c|c|c|c|c|}
\hline \multirow{2}{*}{$\begin{array}{l}\text { Prawdopodo- } \\
\text { bieństwo } \\
\text { Probability }\end{array}$} & \multicolumn{2}{|c|}{$\begin{array}{l}\text { Przepływ w przekroju P1 } \\
\text { Flow in cross-section P1 }\end{array}$} & \multirow{2}{*}{$\begin{array}{l}\text { Redukcja przepływu } \\
\text { Flow reduction }\end{array}$} & \multirow{2}{*}{$\begin{array}{c}\text { Przepływ w przekroju P2 } \\
\text { - bez zbiorników } \\
\text { Flow without } \\
\text { reservoirs }\end{array}$} & \multirow{2}{*}{$\begin{array}{c}\text { Różnica } \\
\text { między P1 i P2 } \\
\text { - bez zbiorników } \\
\text { Difference of flows }\end{array}$} \\
\hline & $\begin{array}{l}\text { ze zbiornikami } \\
\text { with reservoirs }\end{array}$ & $\begin{array}{l}\text { bez zbiorników } \\
\text { without reservoirs }\end{array}$ & & & \\
\hline$[\%]$ & \multicolumn{2}{|c|}{$\left[\mathrm{m}^{3} \cdot \mathrm{s}^{-1}\right]$} & {$[\%]$} & \multicolumn{2}{|c|}{$\left[\mathrm{m}^{3} \cdot \mathrm{s}^{-1}\right]$} \\
\hline 50 & 1,502 & 6,361 & 76,4 & 4,312 & 2,049 \\
\hline 20 & 1,798 & 7,847 & 77,1 & 5,161 & 2,686 \\
\hline 10 & 1,974 & 8,560 & 76,9 & 5,624 & 2,936 \\
\hline
\end{tabular}

Aby ocenić wpływ zbiorników retencyjnych na obszarze portu lotniczego na redukcję przepływów w Potoku Służewieckim, porównano przepływy obliczone w przekroju P1 przy założeniu występowania i braku zbiorników (tab. 4). Wartości przepływów obliczonych w tym przekroju z uwzględnieniem zbiorników były dużo mniejsze niż przepływów obliczonych dla stanu zlewni bez zbiorników. Stopień redukcji przepływów o prawdopodobieństwie przekroczenia 50, 20 i 10\% obliczono z równania:

$$
R=\frac{Q_{b z b}-Q_{z b}}{Q_{b z b}} \cdot 100 \%
$$

gdzie: $Q_{b z b}$ - przepływ maksymalny hydrogramu bez zbiorników $\left[\mathrm{m}^{3} \cdot \mathrm{s}^{-1}\right]$,

$Q_{z b}-$ przepływ maksymalny hydrogramu ze zbiornikami $\left[\mathrm{m}^{3} \cdot \mathrm{s}^{-1}\right]$.

Wartość stopnia redukcji wynosiła od 76,4 do $77,1 \%$.

Wyniki obliczeń przepływów w przekroju P1 dla scenariuszy, które zakładają występowanie i niewystępowanie zbiorników na obszarze portu lotniczego, zilustrowano na rysunku 6. Natomiast na rysunku 7 przedstawiono przykładowe hydrogramy przepływów, które uzyskano z modelu dla dwóch wyżej opisanych scenariuszy obliczeniowych w reakcji na opady o prawdopodobieństwie 20\% i czasie trwania 15 minut. Wysokości tych opadów obliczono przy wykorzystaniu formuły Błaszczyka oraz formuły Bogdanowicz i Stachý’ego. 
Barszcz, M. (2017). Zastosowanie modelu SWMM do obliczenia przepływów i ich redukcji przez zbiorniki na obszarze lotniska Chopina. Acta Sci. Pol. Architectura, 16 (1), 79-91. doi: 10.22630/ASPA.2017.16.1.08.

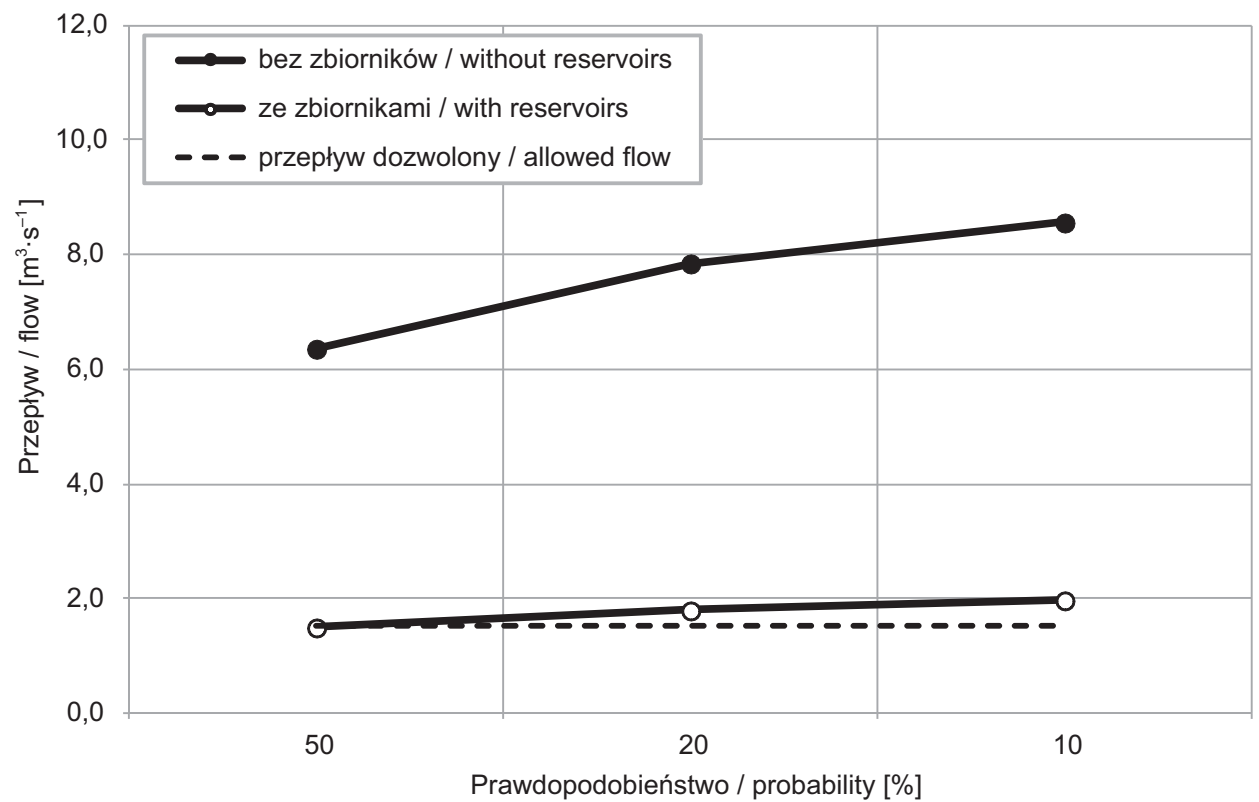

Rys. 6. Przepływy maksymalne obliczone w przekroju P1

Fig. 6. Maximum flows calculated in the cross-section of $\mathrm{P} 1$

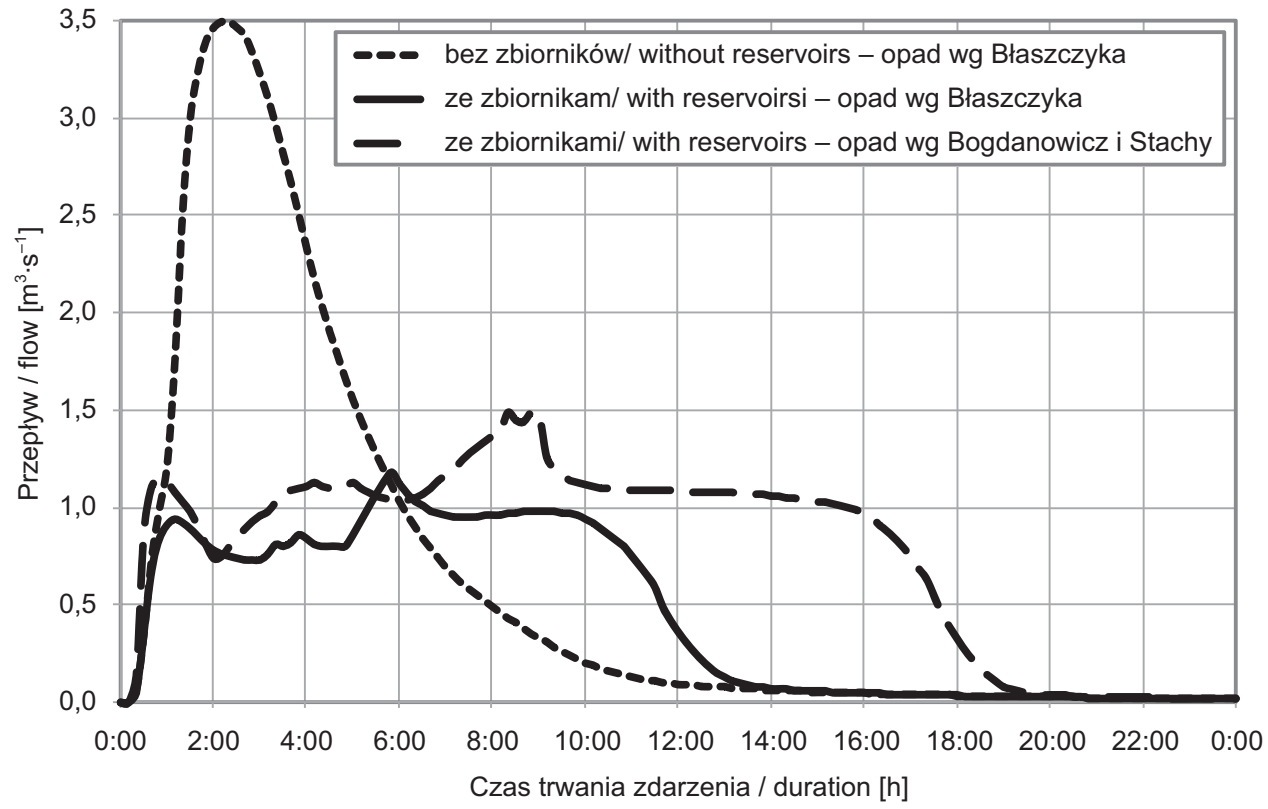

Rys. 7. Hydrogramy przepływów obliczone w przekroju P1

Fig. 7. Hydrographs of flows calculated in the cross-section of P1 


\section{WNIOSKI}

1. Weryfikacja modelu SWMM, adaptowanego dla badanej zlewni, wykazała dobrą zgodność pomiędzy przepływami uzyskanymi z modelu i z pomiarów. Wartość maksymalnego błędu względnego $(22,4 \%)$ była mniejsza od 25\%, którą przyjęto jako umowną granicę akceptacji modelu. Wartości średniego błędu oraz mediany, obliczone dla wartości bezwzględnych błędów symulacji, wynosiły odpowiednio 12,7 i 14,1\%.

2. Przepływ obliczony za pomocą modelu w Potoku Służewieckim w przekroju P1 - poniżej portu lotniczego, w reakcji na opad miarodajny w obliczeniach projektowych istniejących zbiorników retencyjnych był mniejszy od przepływu dopuszczalnego $\left(1,53 \mathrm{~m}^{3} \cdot \mathrm{s}^{-1}\right)$. Natomiast przepływ obliczony w reakcji na opad o prawdopodobieństwie przekroczenia $20 \%$ (takim samym jak dla opadu miarodajnego) i czasie krytycznym trwania opadu wynoszącym dla tego zdarzenia 190 minut (dla opadu miarodajnego przyjęto 15 minut), którego wysokość ustalono według formuły Bogdanowicz i Stachý’ego, był większy od przepływu dopuszczalnego.

3. Wartości przepływów o prawdopodobieństwie przekroczenia 50, 20 i 10\%, obliczone w przekroju P1 dla scenariusza, który zakładał niewystępowanie zbiorników na obszarze portu lotniczego (stan przed 2005 r.), wynosiły od $6,361 \mathrm{do} 8,560 \mathrm{~m}^{3} \cdot \mathrm{s}^{-1}$. Były one dużo większe od przepływu dopuszczalnego. Wartości przepływów o tym samym prawdopodobieństwie, które obliczono w przekroju P1 dla scenariusza uwzględniającego występowanie zbiorników retencyjnych (stan aktualny), wynosiły odpowiednio: 1,502, 1,798 i $1,974 \mathrm{~m}^{3} \cdot \mathrm{s}^{-1}$. Jedynie przepływ o prawdopodobieństwie przekroczenia $50 \%$ był mniejszy od przepływu dopuszczalnego.

4. Przepływy o prawdopodobieństwie przekroczenia 50, 20 i 10\%, obliczone w Potoku Służewieckim w przekroju P2 zlokalizowanym powyżej zbiorników retencyjnych na obszarze portu lotniczego, wynosiły od 4,312 do $5,624 \mathrm{~m}^{3} \cdot \mathrm{s}^{-1}$. Te przepływy są wynikiem odpływu wód deszczowych z części zlewni powyżej lotniska (użytkowanej głównie jako tereny mieszkalne i przemysłowe), której powierzchnia wynosi około $7,7 \mathrm{~km}^{2}$. Różnice w wartościach przepływów pomiędzy przekrojami P1 i P2, wynoszące od 2,049 do 2,936 $\mathrm{m}^{3} \cdot \mathrm{s}^{-1}$, są wynikiem odpływu $\mathrm{z}$ części zlewni pomiędzy tymi przekrojami (głównie $\mathrm{z}$ obszaru portu lotniczego) o powierzchni około $8,8 \mathrm{~km}^{2}$.

5. Wartości przepływów, które obliczono w przekroju P1 z uwzględnieniem ich redukcji przez system retencji wód opadowych na obszarze portu lotniczego (zbiorników retencyjnych i zastawek), były dużo mniejsze od wartości przepływów obliczonych w tym przekroju bez uwzględnienia w modelu systemu retencji. Stopień redukcji przepływów o prawdopodobieństwie przekroczenia 50, 20 i 10\% wynosił od 76,4 do 77,1\%.

\section{PIŚMIENNICTWO}

Barco, J., Wong, K. M. i Stenstrom, M. K. (2008). Automatic calibration of the U.S. EPA SWMM model for a large urban catchment. Journal Hydraulic Engneering, 134(4), 466-474. doi: 10.1061/(ASCE)0733-9429(2008)134:4(466).

Barszcz, M. (2009). Prognoza maksymalnych przepływów prawdopodobnych wywołanych ulewami w zurbanizowanej zlewni Potoku Służewieckiego. Przegląd Naukowy Inżynieria i Kształtowanie Środowiska, 46(4), 3-23.

Barszcz, M. (2015a). Influence of applying infiltration and retention objects on the runoff of rainwater on a plot and catchment scale - case study of the Służewiecki Stream subcatchment in Warsaw. Polish Journal of Environmental Studies, 24(1), 57-65. doi: 10.15244/pjoes/29197.

Barszcz, M. (2015b). Zastosowanie modelu SWMM do prognozy przepływów prawdopodobnych w zlewni miejskiej. Przegląd Naukowy Inżynieria i Kształtowanie Środowiska, 69(3), 209-223.

Beven, K. (2001). Rainfall-runoff modeling. The Primer. England: John Wiley \& Sons, Ltd.

Błaszczyk, W., Stamatello, H. i Błaszczyk, P. (1983). Kanalizacja. Warszawa: Arkady.

Bogdanowicz, E. i Stachý, J. (1997). Maksymalne opady deszczu w Polsce, charakterystyki projektowe. Materiały badawcze IMGW, 23: Seria Hydrologia i Oceanologia. 
Barszcz, M. (2017). Zastosowanie modelu SWMM do obliczenia przepływów i ich redukcji przez zbiorniki na obszarze lotniska Chopina. Acta Sci. Pol. Architectura, 16 (1), 79-91. doi: 10.22630/ASPA.2017.16.1.08.

Decyzja Wojewody Mazowieckiego nr WSR.IV.6811/34-4/07 dnia 14 czerwca 2007 r. - Pozwolenie wodnoprawne na odprowadzanie do Potoku Stużewieckiego wód opadowych i roztopowych z terenu PP „Porty Lotnicze” - Port Lotniczy im. F. Chopina w Warszawie.

Ozga-Zielińska, M. i Brzeziński, J. (1997). Hydrologia stosowana. Warszawa: Wydawnictwo Naukowe PWN.

Park, S. Y., Lee, K. W., Park, I. H. i Ha, S. R. (2008). Effect of the aggregation level of surface runoff fields and sewer network for a SWMM simulation. Desalination, 226, 328-337. doi: 10.1016/j.desal.2007.02.115.

Peterson, E. W. i Wicks, C. M. (2006). Assessing the importance of conduit geometry and physical parameters in karts systems using the storm water management model (SWMM). Journal of Hydrology, 329, 294-305. doi: 10.1016/ j.jhydrol.2006.02.017.

Rossman, L. A. (2010). Storm water management model user's manual version 5.0. Cincinnati, OH: National Risk Management Research Laboratory, U.S. Environmental Protection Agency.

Soil Conservation Service [SCS], (1986). Urban Hydrology for Small Watersheds. Technical Release 55, 2.5-2.8.

Singh, V. P. (1995). Computer Models of Watersheds Hydrology. Colorado, USA: Water Resources Publication.

Szymkiewicz, R. (2000). Modelowanie matematyczne przeplywów w rzekach i kanałach. Warszawa: Wydawnictwo Naukowe PWN.

U.S. Department of Agriculture, Soil Conservation Service [USDA-SCS]. (1975). National Engineering Handbook. Section 4, Washington, DC.

Warwick, J. J. i Tadepalli, P. (1991). Efficacy of SWMM application. Journal of Water Resources Planning and Management, 117, 352-366. doi: 10.1061/(ASCE)0733-9496(1991)117:3(352).

World Meteorological Organization [WMO]. (1994). Guide to hydrological practices. WMO-No. 168 (Fifth edition), Geneva, Switzerland.

\title{
APPLICATION OF THE SWMM MODEL FOR CALCULATION OF FLOWS AND THEIRS REDUCTION THROUGH RESERVOIRS IN THE AREA OF CHOPIN AIRPORT
}

\begin{abstract}
The paper discusses the retention system of storm water in the area of Warsaw Chopin Airport. Describes the adaptation of the SWMM model (Storm Water Management Model) for the Służewiecki Stream subcatchment. Presents results of the calibration and verification of the model, which were carried out on the basis of measured rainfalls and flows, as well of water levels in a retention reservoir and before/after weirs cooperating with reservoirs. The SWMM model was used for calculation of flows with probability of exceedance of 50,20 and $10 \%$, and then for evaluation of reduction of these flows through reservoirs in the area of airport. The degree of reduction of flows ranged from 76.4 to $77.1 \%$.
\end{abstract}

Key words: airport, the SWMM model, rainfall-runoff process, retention reservoirs, reduction of flows 